\title{
Constructing the Other News media representations of a predominantly 'brown' community in New Zealand
}

\begin{abstract}
Research worldwide finds that indigenous, non-white, immigrant and other marginalised communities are subjected to media coverage that negatively and narrowly stereotypes them in comparison to dominant racial groups. In this article, we explore media representations of a predominantly Pacific and lower socio-economic community in New Zealand. The results contribute to the literature regarding media coverage of minority communities through an analysis of 388 news articles, drawing on Freire's (1996/1970) theory of antidialogical action to consider how power is used to marginalise the predominantly Pacific community of South Auckland. The results demonstrate that South Aucklanders are subjected to stereotypes and negative labelling that reinforce their marginalisation and exclusion from mainstream New Zealand culture.
\end{abstract}

Keywords: ethnicity, marginalisation, news media, New Zealand, Pacific peoples, Pākehā, representation

\section{JEAN M ALLEN and TONI BRUCE \\ University of Auckland}

\section{Introduction}

N THIS article, we explore media representations of a predominantly Pacific ${ }^{1}$ and lower socio-economic community in New Zealand, through the lens of Paulo Freire's theory of antidialogical action. For Freire (1970/1996), the power imbalance between what he describes as the haves and have-nots is a form of oppressive action that permits domination over, or prejudicial treatment of, one group or individual by another. In Freire's (1970/1996) conceptualisation of power as primarily oppressive, power imbalances are maintained through antidialogical action, which limits dialogue between the empowered and the marginalised and hinders the ability of marginalised groups to recognise or gain consciousness of their oppression. In this case, antidialogical action is revealed in the way the people and community of South Auckland are represented by the mainstream media, rather than dialogued with. We argue that mainstream media representations of South Auckland reflect antidialogical action in practice-where journalists who 
are rarely of Pacific heritage (Archie, 2014; Wilson, 1990), often unconsciously, exercise their positions of power through processes such as conquest, cultural invasion, marginalisation, manipulation and divide and rule to negatively frame people and events in South Auckland, particularly focusing on crime and violence (see also Borell, 2006; Fepulea'i \& Jean, 2009; 'Ofa Kolo, 1990). We found Freire's framework particularly useful because the perspectives and voices of the people of South Auckland are limited in media coverage, thus providing little space to contest dominant discourses about their community and the ethnic minority groups that make up its greatest proportion.

\section{Representing the Other in Aotearoa/New Zealand}

In many nations, it is not an exaggeration to argue that 'those who control the media control a society's discourses about itself' (Denzin, 1996, p. 319). We take the position that media discourses are neither transparent nor innocent. Instead, they actively create rather than merely reflect realities, and slowly transform the taken-for-granted ways that we make sense of the world and those who live within it (Hall, 1984; McRobbie, 1997). In the New Zealand context, Spoonley and Butcher (2009) argue that media representations have real effects on how individuals and groups of people are perceived.

Concerns about media stereotyping and marginalisation of non-dominant racial or ethnic communities have a long history, and international researchers find that indigenous, non-white, immigrant and other marginalised communities are subjected to media coverage that negatively and narrowly stereotypes them in comparison to dominant racial groups. Indeed, media theorist Stuart Hall argued that "people who are in any way significantly different from the majority — "them" rather than "us"-are frequently exposed to [and] seem to be represented through sharply opposed, polarised, binary extremes' (1997, p. 229). New Zealand studies reflect the international results, finding that the media regularly construct Pacific, Māori and Muslim peoples as Other (e.g., Kabir \& Bourk, 2012; Kupu Taea, 2008, 2014; Loto, Hodgetts, Chamberlain, Waimarie Nikora, Karapu, \& Barnett, 2006; 'Ofa Kolo, 1990; Moewaka Barnes, Borell, Taiapa, Rankine, Nairn, \& McCreanor, 2012; Noorzai, 2014). Indeed, researchers claim that despite implicitly 'claiming to speak for all New Zealanders', much mainstream media coverage is produced 'by Pakeha, for Pakeha and about Pakeha' (Cosgrove \& Bruce, 2005, p. 340; Moewaka Barnes et al., 2012). Such claims are supported by recent surveys finding that Pākehā dominance of journalism exceeds the proportion of Pākehā in the population as a whole. For example, although 74 percent of New Zealanders identified as Pākehā in the 2013 Census, Pākehā comprised 81-86 percent of all journalists (Journalism, 2014; Hollings, 2007; Hollings, Lealand, Samson \& Tilley, 2007; Statistics New Zealand, 2015). Conversely, Pacific people were almost invisible as journalists 
( $<2$ percent), although they make up 7 percent of the New Zealand population; Māori too were under-represented in journalism at 4-6 percent, despite comprising 15 percent of New Zealand's population (Journalism, 2014; Hollings, 2007; Hollings et al., 2007; Statistics New Zealand, 2015). Thus, it should not be surprising that mainstream New Zealand media coverage represents nonPākehā ethnicities through a lens that implicitly normalises Pākehā perspectives (Loto et al., 2006; Moewaka Barnes et al., 2012; Spoonley \& Trlin, 2004). The result is that white power 'reproduces itself regardless of intention, power differences and goodwill' (Dyer, 1997, p. 9). Such representations constitute a form of antidialogical action, in which non-dominant ethnicities are most often represented in a negative light: Pacific people as 'unmotivated, unhealthy and criminal others' (Loto et al., 2006, p. 100), Māori as under-achievers, involved in conflict, violence or crime, or succeeding due to special treatment (McGregor \& Te Awa, 1996; Moewaka Barnes et al., 2012; Nairn, Moewaka Barnes, Borell, Rankine, Gregory, \& McCreanor, 2012; Rankine et al., 2014) and Muslims as 'terrorists, backward and challenging "Western ways" of being' (Noorzai, 2014, p. 53). Through the focus on negative attributes of minority groups, the news media reinforce power relations between the empowered and the marginalised (see also Fanon, 1967).

Loto, Hodgetts, Chamberlain, Waimarie Nikora, Karapu and Barnett's (2006) argument that 'ethnic minorities are significantly disadvantaged in mainstream media coverage, which often functions to silence minority voices, while drawing on majority voices to frame issues of relevance for minority groups' (p. 102; also see Noorzai, 2014) is reinforced by the much larger body of research on Māori representation which concludes that mainstream media 'demonstrate an effective marginalisation of Māori stories, and of Māori voices on issues concerning Māori' (Rankine et al., 2014, p. 228) and 'establish a common sense against which Māori views of the world struggle to gain legitimacy' (Hodgetts, Masters \& Robertson, 2004, p. 459). Thus, by under-using Pacific, Māori or Muslim voices and perspectives, such coverage provides little evidence of dialogue in which power imbalances in representation can be contested, (Freire, 1996). The lack of genuine representative voices within the news media is a reflection of Freire's position that naming of the world on behalf of others is oppressive.

\section{Media power to influence}

Despite increasing public suspicion about knowledge produced by official institutions, including the mainstream media (van Zoonen, 2012), the news media's purportedly objective presentation of information creates a context in which audiences are more likely to view it as a reliable and legitimate source of knowledge about different ethnic and social groups (Maharey, 1990; Spoonley, 1990). For Couldry (2000), it is the individual's belief in media authority, to tell the truth, 
which gives the media influence over our lives. This belief is further naturalised via the media's tendency to repeatedly present a particular view, a process by which certain discourses become increasingly naturalised as truth (Connell, 2008; Cruz \& Lewis, 1994; Hall, 1997; Helsby, Ashbury, Cassey, Ramey, \& Turner, 2005). The process of naturalisation is an expression of power:

Power, it seems, has to be understood here not only in terms of economic exploitation and physical coercion, but also in broader cultural or symbolic terms, including the power to represent someone or something in a certain way-within a certain 'regime of representation'. (Hall, 2013b, p. 249)

Such regimes of representation, constructed from the perspectives of dominant cultural groups, not only influence people's beliefs but can reinforce and widen power imbalances with damaging consequences for those who are misrepresented or narrowly stereotyped (Couldry, 2000). As Richardson (1990) argues,

At the individual level, people make sense of their lives through the stories that are available to them, and they attempt to fit their lives into the available stories. ...If the available narrative is limiting, destructive, or at odds with the actual life, people's lives end up being limited and textually disenfranchised. (p. 26)

\section{Contextualising South Auckland}

It must be understood that South Auckland is a complex term with multiple meanings. However, despite there being a wide range of definitions, there seems little doubt that South Auckland exists as an imagined community (Anderson, 1991) in official, popular and media contexts.

Geographically, defining the boundaries of South Auckland is challenging because it represents a cluster of suburbs rather than a definable land area and its boundaries are dependent on which institution or organisation is defining it. Broadly speaking, South Auckland is a sub-region of New Zealand's largest city, Auckland; other sub-regions include West Auckland, Central Auckland, East Auckland and the North Shore. Although South Auckland has no official status, we adopt the Auckland Council's (2014) definition as the suburbs that are geographically positioned to the south of Auckland's central business district, comprising four Auckland Council Local Board areas that encompass seven main suburbs (Mangere, Otahuhu, Manukau, Manurewa, Papakura, Otara and Papatoetoe) that are home to 274,500 (19 percent) of the $1,415,550$ people living in Auckland (see darker area in Figure 1).

In contrast, the 62 percent of media coverage that named a specific place in South Auckland included a much wider range of suburbs (29), many of which are not geographically clustered but spread across the wider Auckland area (see 


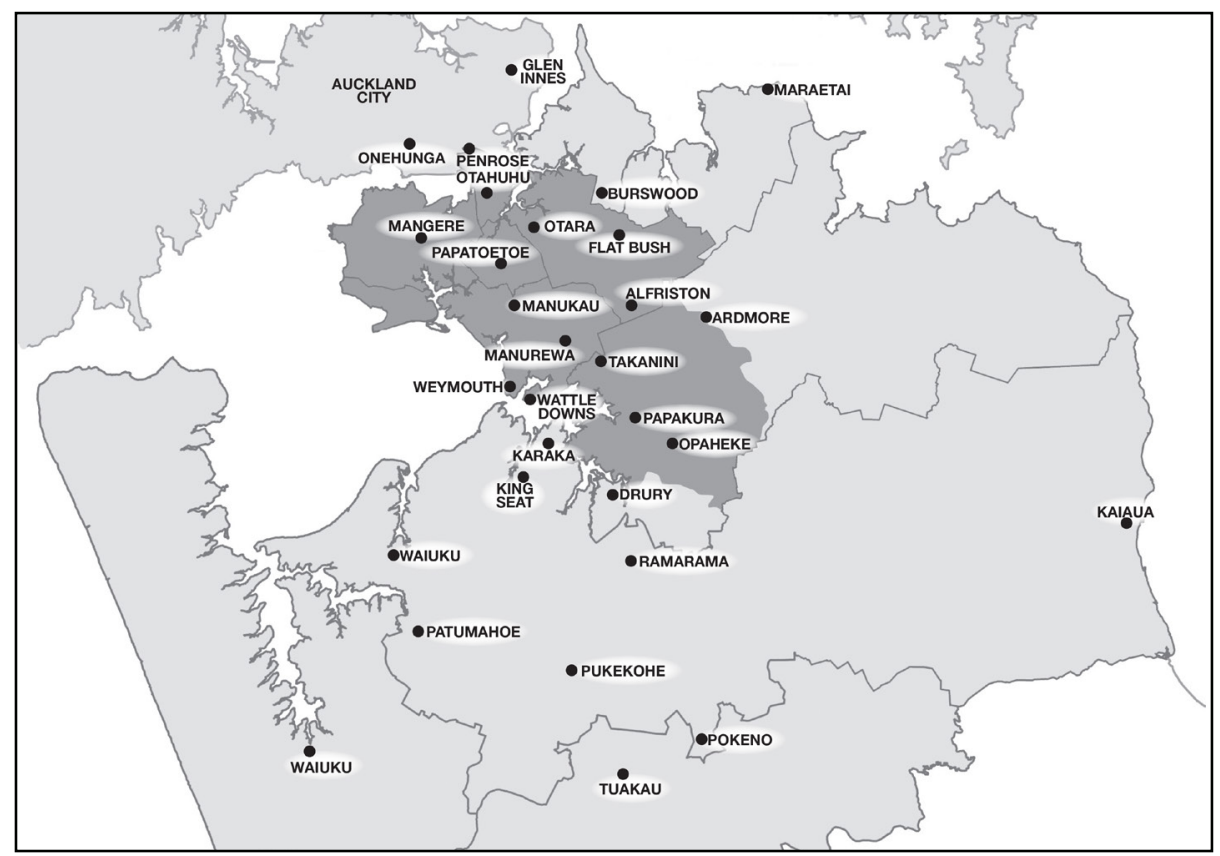

Figure 1: Commonly accepted (darker shade) and news media boundaries of South Auckland.

light grey areas in Figure 1). This more dispersed South Auckland provides evidence of the media's power to flexibly define the boundaries of this imagined community (Anderson, 1991).

South Auckland has an ethnic makeup substantially different from New Zealand as a whole (see Figure 2). Culturally, Auckland is widely regarded as the world's largest Pacific city and has the largest concentration of Pacific peoples. Indeed almost 66 percent of the Pacific population is based in Auckland (Statistics New Zealand, 2014), more than half of whom (52 percent) live in South Auckland. Pacific people are the largest South Auckland ethnic group, and census data shows that their proportion of the South Auckland population (40 percent) is well above their proportion in Auckland (15 percent) or New Zealand overall ( 7 percent). Following waves of purposeful immigration in the 1950s and 1960s in search of higher-paying jobs and a better life (Fairbairn-Dunlop \& Makisi, 2003; Macpherson, Spoonley \& Anae, 2001), almost two-thirds of Pacific people are now New Zealand-born (Statistics New Zealand, 2014). A similar trend is clear for Māori who are over-represented in South Auckland (at 20 percent) compared to Auckland (11 percent) or New Zealand as a whole (15 percent) (see Figure 2). Those who identify with Asian or Other ethnicities are most over-represented in Auckland (23 percent and 4 percent), then in South Auckland (21 percent and 2 percent), compared with their proportion of the New Zealand population (11.8 percent and 1.2 percent respectively) (Statistics New Zealand, 2015). In stark 


\section{Figure 2: Percentage of population by ethnicity, 2013 census}

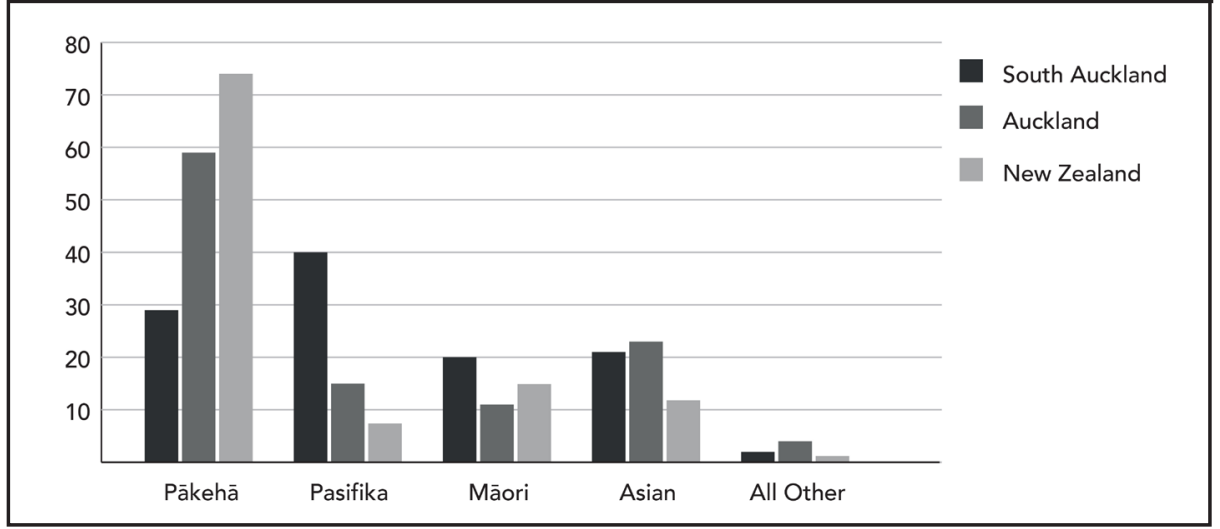

Source: Statistics New Zealand, 2014

contrast, the proportion of Pākehā living in South Auckland (29 percent) is well below their proportion in Auckland (59 percent) or New Zealand as a whole (74 percent), where people who identify as Pākehā remain by far the largest ethnic group (Statistics New Zealand 2014).

The cultural positioning of Pacific people has changed over time, from their initial acceptance as valuable migrant workers in the 1950s and 1960s who were allowed to remain or overstay in New Zealand, working under visitors' permits, even when these permits had expired (Fepulea'i \& Jean, 2009). When the economy slowed down, the government turned its back on the migrant workers and set up police teams whose purpose was to find and deport overstayers (Fepulea'i \& Jean, 2009). However, although the majority of overstayers were from Europe and North America, police focused on the one-third of overstayers from the Pacific, entering homes early in the mornings to demand proof of residency — an action that became known as the Dawn Raids (Fepulea'i \& Jean, 2009; Spoonley, 2012). However, despite comprising only one-third of overstayers, 86 percent of prosecutions for overstaying were from the Pacific (Spoonley, 2012; Misa, 2010). In addition, white privilege was evident in the way that European and North American overstayers were seldom included in the national media conversation regarding overstayers. The selective focus on Pacific overstayers fragmented parts of the Pacific community, as many who were New Zealand residents turned on their overstaying friends, reported overstaying family members to police or resorted to secrecy to ensure overstaying individuals could stay (Fepulea'i \& Jean, 2009). The Dawn Raids are an example of Freire's (1996) marginalisation and divide and rule strategies, in that Pacific people were disproportionately targeted through government policy. More than 30 years later, South Auckland is still haunted by the ensuing discourse of Pacific people as criminal, dangerous and unemployed (Borell, 2006). As a 
result, South Auckland has become identified in the popular imagination as a 'brown' place - a high risk, tough area of crime, poverty and violence, where dysfunction, disorder and gangs are commonplace (Borell, 2006; Fitzpatrick, 2013; Nakhid, Tanielu \& Collins, 2009). This marking of difference within the news media alienates and stigmatises the people in South Auckland, resulting in the community being marginalised and separated from wider society. In contrast, people living in South Auckland have identified many positives to living in the community, including a strong sense of belonging and safety (Nakhid, 2012; Nakhid, Tanielu \& Collins, 2009). These conflicting perspectives reinforce Jhally and Hall's (1997) argument that noting what is missing from media coverage is just as important as noting what is present, due to the news media's power to naturalise particular realities (Couldry, 2000).

\section{Analysing mainstream media representations}

To investigate how the news media were representing South Auckland, the first author conducted a content and textual analysis of media coverage, beginning with a preliminary search in July 2014, using the search term 'South Auckland', on four major news websites. These included the two most-visited newspaper sites-Fairfax aggregator, Stuff.co.nz (1.7 million unique monthly visitors) and The New Zealand Herald, nzherald.co.nz (1.3 million) (Riddiford, 2015)—and two television news stations - One News and 3 News, that attract higher average viewer ratings than alternative televised news options (Fyers, 2015). The search generated over 600,000 results, ranging from 490,000 on Stuff to 'approximately 1000 ' for the Herald. As different sites organised stories differently (some chronological and some not), a manageable sample was constructed by limiting analysis to the first 10 pages or 100 articles from each source. This approach resulted in 388 articles (including 205 images) after duplicates were eliminated: Herald (100), Stuff (93), One News (99) and 3News (96).

The primary methods were content and textual analysis. Content analysis provides a way of counting and identifying common themes, concepts, language and structures (Bruce, Hovden \& Markula, 2010). Major categories for analysis were derived from other New Zealand studies of representations of ethnicity, immigrant and other forms of marginalised identities (e.g., Bruce \& Scott-Chapman, 2010; Hodgetts et al., 2004; Loto et al., 2006; Meijer, 2013; Noorzai, 2014; Spoonley \& Butcher, 2009). Key patterns from the content analysis were then explored in more depth through textual analysis of 35 newspaper articles of two significant events, treating the media texts as 'material traces' of how journalists make sense of the world (McKee, 2003, p. 15). The first was an armed robbery in which two pawn shop workers were shot and killed (Dougan, 2014). The second involved two separate school stabbings on the same day (Ryan, 2014; Smith, 2014). The analysis focused on the language used to describe South Auckland, 
the perpetrators and victims, and the incident and reactions to it, as a way of uncovering media discourses and connecting them to the wider sociocultural context (Hall, 1997; McKee, 2003).

Freire views the oppressor/oppressed relationship as the physical, spiritual and mental domination of one group or individual over the other, which results in the group and/or individual feeling, and sometimes believing, they are less human. While Freire's theory was concerned with the pedagogy of education, his larger theoretical concepts regarding the process and applications of power can and have been recontextualised to encompass a range of research fields. As Higgins (1982) states, 'His theory of education is not confined to classroom interactions but embraces the hearts and minds of the people so that they can "change their world"' (p. 88). Therefore, we adopt Freire's theory of antidialogical action in this project to gain a deeper understanding of how media power contributes to patterns of representation of South Auckland. We present the results through the lens of four key elements of Freire's antidialogical action. Briefly, conquest removes the rights of the marginalised to name their world, leaving the marginalised voiceless, while cultural invasion involves the imposition of the dominant group's 'own view of the world' (Freire, 1996, p. 133). Divide and rule is defined by Freire as alienation being used as a dimension to prevent unity among the oppressed or marginalised, and manipulation is concerned with the way those in power use persuasive measures to gain conformity to their ideological views, such as the emphasis on economic accumulation as a measure of success (O'Connor, 2014); manipulation works to blame individuals and ignores structural aspects that can effect personal achievement such as social class, privilege and race (Fitzpatrick, 2013). In the remainder of the article, we weave together the results of the media analysis, theory and existing literature to demonstrate how media representations act as a form of what Freire called a 'crafty instrument for the domination of one person by another' (1996, p. 70). We argue that media representation of South Auckland and its peoples through "unexamined Pākehā assumptions concerning what is "real" and what counts as legitimate knowledge' (Hodgetts et al., 2004, p. 459) is a form of antidialogical action that results in the framing of South Auckland as a place of Otherness.

\section{Naming the Other: South Auckland as a place of crime and violence}

Overall, the media analysis reinforced existing popular, research and government understandings of South Auckland, marking it as a place of difference that does not reflect the cultural norms of mainstream (Pākehā) New Zealand society. Media coverage of South Auckland incorporated diverse topics (see Figure 3) including development of buildings, housing and infrastructure, community support, sport, politics, the arts, education and the economy. However, it marked South Auckland primarily as a place of crime and danger, with more 


\section{Figure 3: Topics covered in news coverage of South Auckland}

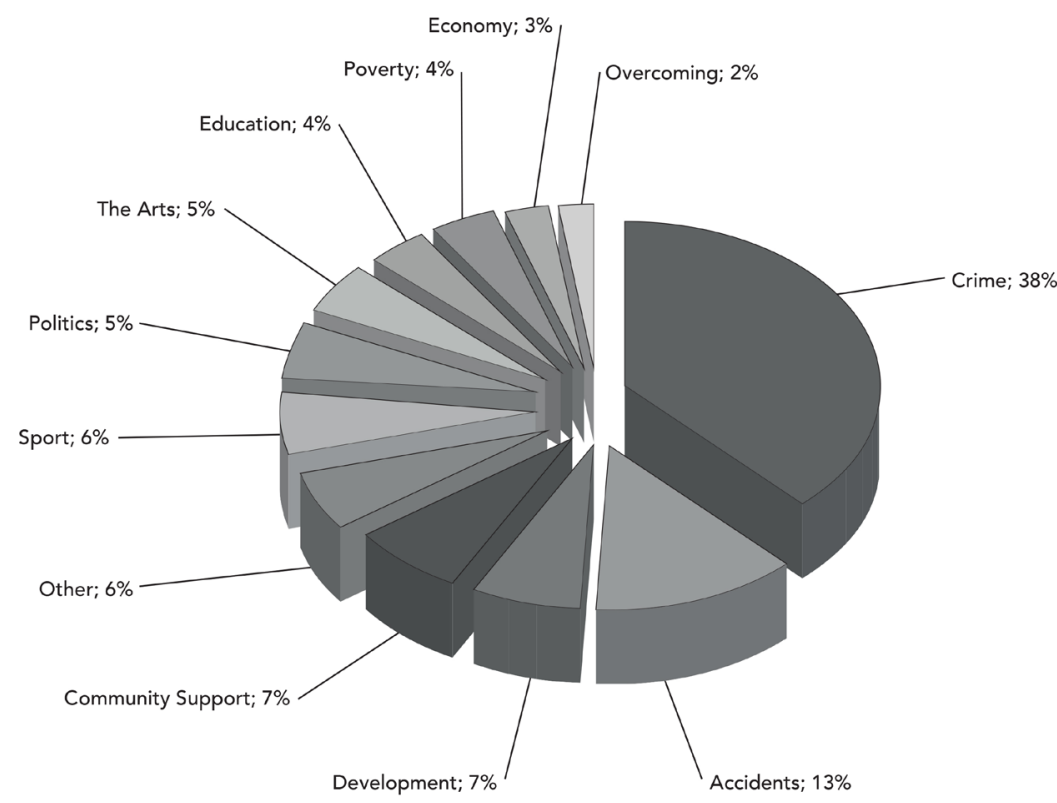

than half the articles focusing on either crime (38 percent) or accidents (13 percent). Although the focus on crime may reflect a trend of crime news increasing as a proportion of hard news in New Zealand newspapers (McGregor, 2002), it is disproportionately higher than the 19.3 percent McGregor (2002) identified, and exceeds even the highest level reported in an international metaanalysis of crime reporting (1.6 percent to 33.5 percent) (Wardle, 2008). Instead, it appears more representative of a recent large-scale content analysis that found high levels of crime reporting in relation to Māori (McCreanor et al., 2014; Rankine et al., 2014), a finding reinforced by other research that finds when media cover Māori, the focus is bad news (McGregor \& Comrie, 2002; Walker, 2002). 'Ofa Kolo (1990) also identified a process by which mainstream media sensationalised and misrepresented crime by Pacific peoples, blowing it 'out of all proportion' (p. 121) and strengthening the popular image of Pacific Island-dominated suburbs as unsafe.

Thus, by reporting crime in South Auckland (and incorporating crime in other Pākehā-dominated areas in this representation), the media marked difference and sent the message that South Auckland, with its large non-Pākehā population, was a dangerous place. This construction was particularly apparent in headlines, such as Armourguard cash transit van held up at gunpoint (APNZ, 2014b), Pawn shop killings (Dougan, 2014), Two stabbing incidents in South Auckland (Ryan, 2014), Man fighting for life after South Auckland assault (APNZ, 2014a), 
and South Auckland hit by most burglaries (Kidd, 2014b). An example of the media's power to flexibly define South Auckland while articulating it to crime and violence appeared in an article headlined Bottle of spirits smashed over store employee's head (APNZ, 2014c). This article used a South Auckland identifier despite the incident taking place in East Auckland (Howick Local Board), an area whose population is predominantly Pākehā (55 percent) and Asian (39 percent), with less than 5 percent Pacific peoples (Statistics New Zealand, 2015). This marking of difference by the media demonstrates the media's power to speak for, name and associate South Auckland with violence and crime, even when the violence takes place in a primarily Pākehā suburb. It thus dissociates violence from the dominant ethnic group and articulates it to 'brown' communities of Pacific and Māori peoples, which is likely to influence how people understand South Auckland. As Hall (2013b) states, 'we can't help reading images of this kind of "saying something", not just about the people or the occasion, but about their "otherness", their "difference"" (p. 219).

South Auckland was also constructed as a place of extreme violence in coverage of two stabbing incidents at or near schools (Ryan, 2014), which included 24 articles, 16 images and five videos. In this example, the violence was represented as extreme in comparison to other areas of Auckland and New Zealand. For example, Boyer (2014) reported, 'for millennia kids have had fights...but stabbing people isn't normative' (para. 22). Reinforcing the headlines and text, three-quarters of the images involved emergency services, including ambulances and police setting up a sharp contrast between normalised perceptions of schools as safe spaces and South Auckland schools as places of danger. Such contrasts play an important role in how we read or understand images represented in the media (Hall, 2013b). Comments reported in the articles also emphasised the otherness of South Auckland violence: such as 'I'm in shock by what's happened, that a child has been stabbed while at school' (Ryan, 2014, para. 37), and 'most of us do not accept that the allegations of weapons would be a part of a schoolboy fight' (Boyer, 2014, para. 19). Further, the textual analysis revealed that low socioeconomic status and high numbers of young people were seen by health professionals as contributing factors to such incidents. For example, Boyer (2014) quoted an unnamed child psychologist as stating:

I think it frightens anybody when you hear of young children in a situation where allegedly there is a weapon being used, but that's symptomatic of a community that has a high proportion of young people in it...Obviously [emphasis added] you are talking about deprivation, family difficulties all the things that you associate with poor outcomes for kids. (para. 23)

In this example, the use of such images and quotes, and an emphasis on violence in language (167 mentions of variations of stab, fight, violent, attack, serious, 
weapon, assault and wound) implicitly normalises South Auckland in violent and non-normative terms.

In contrast to the emphasis on crime and difference, only 20 percent of articles took an encouraging or uplifting approach. For example, South Auckland was represented as a place with many musically talented individuals: 'Forget X Factor, on the streets of South Auckland you can bump into the next big Kiwi star on the bus or in The Warehouse' (Day 2013, para. 1). Day further reiterated this point writing that, 'the exploration of South Auckland revealed hidden talents on every corner' (2013, para. 4). Other representative headlines included: Apiata steps up for Big Buddy plan (Mason \& Tapaleao, 2014), South Auckland a 'safe place' (Manukau Courier, 2008) and South Auckland boy's honesty rewarded (Davis, 2010). However, closer examination identified 'sharply opposed...binary extremes' (Hall, 2013b, p. 219), that juxtaposed encouraging and uplifting aspects of the community with negative aspects. For example, "We are strong. We are a safe city." That's the message from city leaders and police to Manukau residents reeling after three killings in nine days' (Manukau Courier, 2008, para. 1). Thus, the initial representation of South Auckland as a safe place was reconstructed, by reminding readers of three killings that occurred in the area within nine days. In this way, the news media demonstrated the power to frame articles according to the dominant view of South Auckland as being a place of danger rather than safety. Another example appeared in a story about a young man honored with an award, headlined Martial arts saves street kid (Tapaleao, 2014), that began with the sentence 'When you are surrounded by people fixated on drugs, alcohol and violence, there are only two things you can do-join them, or turn away' (para. 1) and included other statements such as 'hanging out on the streets... and getting up to no good was the norm' (para. 6). Freire (1996) would view the use of such binaries as a form of manipulation that reinforces dominant Western ideologies. In media representations of South Auckland, such manipulation reinforces it as a dangerous and non-normative space. This in turn results in further marginalisation and exclusion for those who live there.

Difference was also constructed through the marking of ethnic difference. Existing research shows that ethnic minorities are often represented within the New Zealand news media in ways that prioritise negative aspects (Hodgetts et al., 2004; Spoonley \& Trlin, 2004; Walker, 2002), such as representing Pacific peoples and Māori as violent, criminal, others ('Ofa Kolo, 1990; Nairn et al., 2012; Walker, 2002). Such associations are often connected through the use of ethnic tagging which explicitly identifies the ethnicity or ethnicities of the individuals involved in news reports (Loto et al., 2006). Although ethnic tagging was explicit in the text of only 18 percent of articles (95 mentions), Pacific people were by far the most tagged, being identified in 73 percent of the explicitly tagged coverage (58 percent Pacific Islander, 8 percent Tongan, 6 perecent Samoan, 1 percent Niuean), 
followed by Māori (22 percent), which reinforces South Auckland as a brown place (see Figure 4). The dominant New Zealand ethnicity, Pākehā, was mentioned in only one article (2 percent), with similarly limited identification of South Auckland residents of Indian, Asian, Niuean or Brazilian heritage (1 percent each).

Reinforcing the association between brownness and crime, ethnic tagging was

\section{Figure 4: Ethnic tagging in the text of articles}

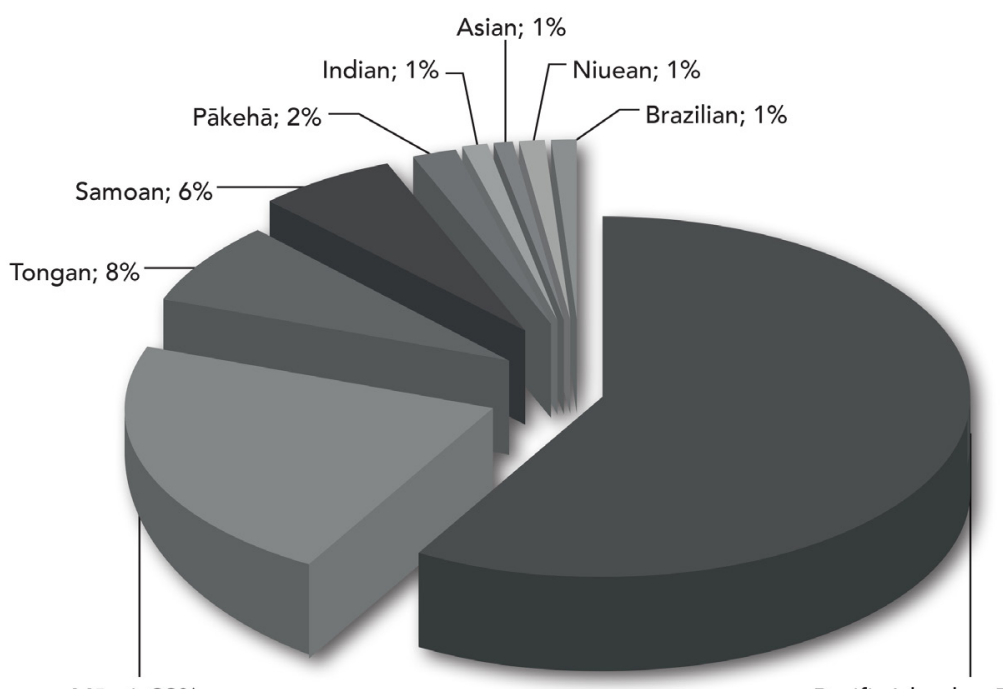

Māori; $22 \%$

Pacific Islander; $58 \%$

most common in crime stories (38 tags), and Pacific people were overwhelmingly tagged in these stories (84 percent of tags), followed by Māori (13 percent) and Indian ( 3 percent). Further, the way in which brownness is generalised was visible in media reporting on crime, such as 'police are appealing for sightings of a Māori or Pacific Island man aged in his 20s' (Weekes, 2014, para. 12), 'The man who robbed the store is described as male, of Māori or Polynesian descent' (Beswick, 2013, para. 8), and 'The person is described as a Māori or Polynesian of medium build and height with bushy afro-type hair tied back' (Kidd, 2014a, para. 7). This kind of coverage can influence racist attitudes towards Māori and Pacific people for, as Hook (2009) states, 'there is a perception held by the general public that Māori and Pacific Islanders are responsible for most of the crimes perpetrated on the streets of New Zealand' ( $p$. 3). Use of racial profiling and ethnic tagging works by describing and defining a group of people, to the point that particular images of these groups will result in fixed definitions of who they are (Loto et al., 2006 Jhally \& Hall, 1997). The linking of certain ethnicities with crime and violence is a manifestation of the power the news media has to name and frame minority groups (Couldry, 2000; 
Gabriel, 1998; Loto et al., 2006; Spoonley \& Trlin, 2004). Thus, the salience of Pacific Island ethnicities within news media reporting of crime helps create powerful negative associations that contribute to the creation of simplistic stereotypes of Pacific people. For, as Jhally and Hall (1997) argue, 'what we know about the world is how we see it represented' (p. 20). Hence, what we see in news media regarding Pacific people and South Auckland becomes what we know about them, to a point where 'whenever you see those people [emphasis added], you will assume that they have those characteristics [emphasis added]' (Jhally \& Hall, 1997, p. 19). Although ethnic tagging of minorities was used in 5 percent of articles that presented positive aspects such as overcoming hardships, these stories were overshadowed by more negative discourses.

Although ethnicity was not explicitly named in many articles, it was evident in 56 percent of images. Accepting the problematic nature of defining ethnicity on the basis of images alone, it initially appeared that ethnicity in images showed a different pattern, with a relatively even spread of brown (48 percent) and white (50 percent) ethnicities across the 90 images. However, further analysis revealed that white ethnic tagging was connected to culturally powerful positions that uphold law and order (such as police or government representatives) or as victims, while brown ethnic tagging tended to reinforce the stereotypical image of South Auckland as a poor, criminal area (through images of perpetrators or people living in the area where crime took place). For example, in several crime-related articles, Pākehā police were presented as protecting and or resolving issues in South Auckland, which carries the implication that Pākehā Police are needed to bring order to the abnormal neighbourhoods of 'brown' South Auckland. Thus, whether in written or visual form, ethnic tagging appears part of a process of othering, as part of 'racialised discourse ... structured by a set of binary oppositions. ... the powerful opposition between "civilisation" (white) and "savagery" (black)'(Hall, 1997, p. 243). Clearly, when ethnic tagging was used, it highlighted non-dominant ethnicities and/or association of those ethnicities with crime. This finding supports 'Ofa Kolo's (1990) argument that 'ethnic tagging is a major feature in media reports only when the subjects of those reports are not members of the majority culture' (p. 121). It also reinforces Fiske's (1993) argument that the power of the majority lies in its ability not to be named. Despite 29 percent of people in South Auckland identifying as Pākehā, the failure to identify their ethnicity (or visually presenting their ethnicity primarily in images as police or government officials who may or may not live in the area) is another form of marking South Auckland as a place where only brown, criminal, others live.

A final form of oppression is the denial of voice. The news media select who gets to speak, especially regarding minority issues, and the content analysis showed how rarely members of the South Auckland community were quoted regarding issues in their community. The most privileged voices were those 
who held power, such as the Police, lawyers, judges, and government or council representatives, who comprised 37 percent of all sources. In contrast, only 15 percent of community leaders(2) were quoted. Members of the public comprised 20 percent of the quoted sources, often as bystanders and witnesses to events. Featured individuals ( 21 percent of sources) also included people in power such as business leaders, as well as sport stars. However, through the overall lack of representation of South Auckland voice within the news media, South Aucklanders are denied the ability to speak back or challenge what is said. The lack of ability to speak back or challenge the representation of South Auckland is seen by Freire (1996) as an example of conquest, where minorities' rights to define, name or speak are taken away. The lack of South Auckland voice in news coverage results in the news media's representation of South Auckland being left unchallenged. This is why Freire views dialogue as such as an important aspect of liberation; in order to change the way society works we need to be able to participate in true and honest conversations, involving reflection and action, not mere 'verbalism' (p. 68).

\section{Conclusions}

We conclude that Freire's (1996) antidialogical action is evident in the way that that the media localises, segregates and sets South Auckland apart from the rest of Auckland and New Zealand, through highlighting issues of crime and violence, associating brownness with non-normative behaviour and limiting the ability of the people of South Auckland to publicly define their lives and experiences. Freire advocated for the need for dialogue to occur between those in positions of power and the marginalised. He argued that dialogue "must not be a situation where some name on behalf of others. It is an act of creation; it must not serve as a crafty instrument for the domination of one person by another" (Freire, 1996, p. 70). However, we suggest that, intentionally or not, news media coverage of South Auckland becomes a "crafty instrument for domination' through perpetuating and reinforcing understandings of South Auckland as brown and abnormal, thus creating boundaries between it and other parts of Auckland and New Zealand society more broadly. For Wetherell and Potter (1992) 'power develops through "normalisation", through defining what is usual and habitual and to be expected, as opposed to the deviant and exceptional' (p. 84). The media analysis revealed that Pacific people and the wider area of South Auckland are normalised as different and inferior in comparison to Pākehā cultural norms.

Through holding a privileged position as definers of reality, journalists represent aspects of society that they deem to be important and in line with their ideological beliefs. Perhaps because the majority of journalists are Pākehā, we should not be surprised that representations of other ethnicities reflect dominant 
understandings of ethnic difference, thus framing South Auckland as Other. Media representations of South Auckland marked it primarily as a place of violence and crime (although it is not only this). These negative aspects were often linked to ethnicity through the use of ethnic tagging which in New Zealand is frequently used as a way of privileging Pākehā norms and silencing minority voices (Loto et al., 2006).

We include ourselves among the many researchers that McKee (2003) describes as wanting 'to change the kinds of texts that are published, particularly by journalists in newspapers and in television news, wishing for texts which are less racist, less sexist, less homophobic, less capitalist, for example' (p. 53). However, we conclude on the basis of this analysis that South Auckland is viewed as other, a place that has been compared, categorised, judged to be culturally different and thus segregated and excluded. This process of othering has been used in order to compare minority groups to that of the majority, in line with dominant ideologies that focus on Pākehā cultural superiority while viewing minority issues or cultural norms as abnormal and inferior. Thus, if we truly seek change, we must encourage real dialogue between the producers of news and the people of South Auckland, in order to challenge, disrupt and reconceptualise Pacific people and other minority groups as part of the mainstream.

\section{Notes}

1. A term commonly used in New Zealand to identify ethnicities that are indigenous to the Pacific Islands. The largest groups comprise those whose heritage is Samoan (48.7 percent of Pacific people in New Zealand), Cook Islands Māori (20.9 percent), Tongan (20.4 percent) or Niuean (8.1 percent) (Statistics New Zealand, 2014).

2. Community leaders refer to people who are held in high regard in the community but are not part of the government or council.

\section{References}

Anderson, B. (1991). Imagined communities. Manhattan, NY: Verso.

APNZ. (2014a, March 28). Man fighting for life after South Auckland assault. The New Zealand Herald online. Retrieved from www.nzherald.co.nz/nz/news/article. cfm?c id=1\&objectid=11227939

APNZ. (2014b, July 10). Armourguard cash transit van held up at gunpoint. The New Zealand Herald. Retrieved from www.nzherald.co.nz/nz/news/article.cfm?c id $=1 \&$ objectid $=11291310$

APNZ. (2014c, July 10). Bottle of spirits smashed over store employee's head. The New Zealand Herald. Retrieved from www.nzherald.co.nz/nz/news/article.cfm?c id $=1$ \&objectid $=11291261$

Archie, C. (2014). Maori affairs: A field of reporting unique to Aotearoa. In G. Hannis (Ed.), Intro: A beginner's guide to journalism in 21st-century Aotearoa New Zealand (pp. 75-89). Lower Hutt, New Zealand: New Zealand Journalists Training Organisation. 
Auckland Council. (2014). Wards. Retrieved from www.aucklandcouncil.govt.nz/EN/ AboutCouncil/representativesbodies/LocalBoards/Wards/Pages/home.aspx

Beswick, A. (2013, September 26). Gunman on run near south Auckland mall. 3News. Retrieved from www.3news.co.nz/nznews/gunman-on-run-near-south-auckland-mall2013092610\#axzz3fdS6AwdO

Borell, B. (2006). Living in the city ain't so bad: Cultural identity for young Maori in South Auckland. In J. H. Lui, T. McCreanor, T. McIntosh \& T. Teaiwa (Eds.), New Zealand identities: departures and destinations (pp. 369-400). Wellington, New Zealand: Victoria University Press.

Boyer, S. (2014, June 26). Bullying before scissor fight alleged. The New Zealand Herald. Retrieved from www.nzherald.co.nz/nz/news/article.cfm?c_id=1\&objectid=11281837

Bruce, T., Hovden, J., \& Markula, P. (Eds.). (2010). Sportswomen at the Olympics. A global Content Analysis of Newspaper coverage. Rotterdam, The Netherlands: Sense.

Bruce, T., \& Scott-Chapman, S. (2010). New Zealand: Intersections of nationalism and gender. In T. Bruce, J. Hovden \& P. Markula. (Eds.), Sportswomen at the Olympics: A Global Comparison of Newspaper Coverage (pp. 275-287). Rotterdam: Sense Publishers.

Connell, B. (2008). Exploring the media: text, industry, audience. Leighton Buzzard, United Kingdom: Auteur.

Cosgrove, A., \& Bruce, T. (2005). 'The way New Zealanders would like to see themselves': Reading white masculinity via media coverage of the death of Sir Peter Blake. Sociology of Sport Journal, 22, 336-355. Retrieved from www.cabdirect.org.ezproxy. auckland.ac.nz/abstracts/20053172146.html;jsessionid=35081D49645F9196EF5838 06AA1D64BB?freeview=true

Couldry, N. (2000). The place of media power: Pilgrims and witnesses of the media age. London, England: Routledge.

Cruz, J., \& Lewis, J. (1994). Reflections upon the Encoding/Decoding model: an interview with Stuart Hall. In J. Cruz \& J. Lewis (Eds.), Viewing, reading, listening: audiences and cultural reception (pp. 253-274). Boulder, CO: Westview Press.

Davis, M. (2010, February 1). South Auckland boy's honesty rewarded. 3News. Retrieved from www.3news.co.nz/nznews/south-auckland-boys-honesty-rewarded2010020117\#axzz3f9fxhS00

Day, S. (2013, June 23). Web-based show reveals South Auckland talent. Stuff.co.nz. Retrieved from www.stuff.co.nz/entertainment/tv-radio/8830341/Web-based-showreveals-South-Auckland-talent

Denzin, N. K. (1996). More rare air: Michael Jordan on Michael Jordan. Sociology of Sport Journal, 13(4), 319-342. Retrieved http://journals.humankinetics.com.ezproxy. auckland.ac.nz/ssj-back-issues/ssjvolume13issue4december/forewordmorerareairmichaeljordanonmichaeljordan

Dougan, P. (2014, July 21). Pawn shop killings: accused keeps name suppressed. The New Zealand Herald. Retrieved from www.nzherald.co.nz/nz/news/article.cfm?c $\mathrm{id}=1$ \&objectid $=11296782$

Dyer, R. (1997). White: Essays on race and culture. Abingdon Oxon, UK: Routledge.

Fairbairn-Dunlop, P., \& Makisi, G. (2003). Making our place: Growing up PI in New Zealand. Palmerston North, New Zealand: Dunmore Press.

Fanon, F. (1967). Black skin, white masks. Manhattan, NY: Grove Press.

Fepulea'i, D. (Director) \& Jean, R. (Producer). (2009). Dawn raids. (TV Documentary). New Zealand: Isola Productions.

Fiske, S. T. (1993). Controlling other people. The impact of power on stereotyping. American Psychologist 48(6), 621-628. doi: 10.1037/0003-066X.48.6.621 
Fitzpatrick, K. (2013). Critical pedagogy, physical education and urban schooling. Manhattan, NY: Peter Lang.

Freire, P. (1996). Pedagogy of the oppressed (Rev. ed.). London, England: Penguin Books (Original work published 1970).

Fyers, A. (2015, April 22). The numbers behind Campbell Live. Stuff.co.nz. Retrieved from www.stuff.co.nz/entertainment/tv-radio/67945132/The-numbers-behindCampbell-Live

Gabriel, J. (1998). Whitewash. Racialized politics and the media. Manhattan, NY: Routledge.

Hall, S. (2013a). Introduction. In S. Hall, J. Evans \& S. Nixon (Eds.), Representation (2nd ed., pp. xvii-xxvi). London, England: Sage in association with the Open University.

Hall, S. (2013b). The spectacle of the 'other'. In S. Hall, J. Evans \& S. Nixon (Eds.), Representation (2nd ed., pp. 215-287). London, England: Sage in association with the Open University.

Hall, S. (1997). The spectacle of the 'other'. In S. Hall (Ed.), Representation: cultural representations and signifying practices (pp. 223-290). London, England: Sage.

Hall, S. (1984). The narrative construction of reality. Southern Review, 17, 2-17

Helsby, W., Ashbury, R., Cassey, J., Ramey, M., \& Turner, P. (2005). Understanding representation. London, England: British Film Institute.

Higgins, K. (1982). 'Making it your own world': Women's studies and Freire. Women's Studies International Forum, 5(1), 87-98. doi: 10.1016/0277-5395(82)90068-1

Hodgetts, D., Masters, B., \& Robertson, N. (2004). Media coverage of 'decades of disparity' in ethnic morality in Aotearoa. Journal of Community \& Applied Social Psychology, 14, 455-472. doi: 10.1002/casp.792

Hollings, J. (2007). Still European and female, but older: Profiling the New Zealand Journalist. Pacific Journalism Review, 13(1), 183-195. Retrieved from http://search. informit.com.au.ezproxy.auckland.ac.nz/documentSummary; $\mathrm{dn}=64674983958528$ 7;res=IELHSS

Hollings, J., Lealand, G., Samson, A., \& Tilley, E. (2007). The Big NZ journalism survey: Underpaid, under-trained, under-resourced, unsure about the future-but still idealistic. Pacific Journalism Review, 13(2), 175-197. Retrieved from http:// search.informit.com.au.ezproxy.auckland.ac.nz/documentSummary;res=IELHSS; $\mathrm{dn}=839098001418024$

Hook, G. R. (2009). The criminalization of Māori and Pacific Islanders under the Domestic Violence Act 1995. MAI Review, 3, 1-8. Retrieved from www.review.mai.ac.nz Jhally, S. \& Hall, S. (1997). Representation and the media [Video]. Northhampton, England: Media Education Foundation

Journalism 2014 (2014). Infometrics. Competenz. Available from: www.competenz.org. nz/assets/Industry-Insights/Journalism-2014.pdf

Kabir, S. N., \& Bourk, M. (2012). Representing Islam and Muslims in New Zealand newspapers. Journal of Muslim Minority Affairs, 32(3), 324-338. Retrieved from www.tandfonline.com.ezproxy.auckland.ac.nz/doi/abs/10.1080/13602004.2012.72 7293\#.Vkpl2nYrLmE

Kidd, R. (2014a, July 22). Auckland grandmother bashed in home. Stuff.co.nz. Retrieved from www.stuff.co.nz/national/crime/10296080/Auckland-grandmother-bashed-in-home

Kidd, R. (2014b, July 22). South Auckland hit by most burglaries. Stuff.co.nz. Retrieved from www.stuff.co.nz/national/crime/10291306/South-Auckland-hit-by-mostburglaries

Kupu Taea. (2008). How news items represent Māori: A checklist for news media consumers 
to assess news stories [online]. Auckland, Kupu Taea. Available from www.trc.org.nz/ research-about-media-and-te-tiriti

Kupu Taea. (2014). Alternatives to anti-Māori themes in news media [online]. Auckland, Kupu Taea. Available from: www.trc.org.nz/alternatives-anti-maori-themes-news-media Loto, R., Hodgetts, D., Chamberlain, K., Waimarie Nikora, L., Karapu, R., \& Barnett, A. (2006). Pacific in the news: the portrayal of Pacific peoples in the New Zealand press. Journal of Community \& Applied Social Psychology, 16, 100-118. doi: 10.1002/casp.848

Macpherson, C., Spoonley, P., \& Anae, M. (2001). Pacific peoples in Aotearoa: an introduction. In C. Macpherson, P. Spoonley \& M. Anae (Eds.), Tangata O Te Moana Nui: The Evolving Identities of Pacific Peoples in Aotearoa/New Zealand (pp. 11-15) . Palmerston North, New Zealand: Dunmore Press.

Maharey, S. (1990). Understanding the mass media. In P. Spoonley \& Q. Hirsh (Eds.), Between the lines: racism and the New Zealand media (pp. 13-25). Auckland, New Zealand: Heinemann Reed.

Manukau Courier. (2008, June 18). South Auckland a 'safe place'. Stuff.co.nz. Retrieved from www.stuff.co.nz/auckland/494073

Mason, C. \& Tapaleao, V. (2014, June 27). Apiata steps up for Big Buddy plan. The New Zealand Herald. Retrieved from www.nzherald.co.nz/nz/news/article.cfm?c $\mathrm{id}=1 \&$ objectid=11282559

Mathers, J. (2013, September 29). Reinventing South Auckland. The New Zealand Herald. Retrieved from www.nzherald.co.nz/nz/news/article.cfm?c_id=1\&objectid=11131749

McClure, M. (2012). 'Auckland places_-South Auckland', Te- Ara-the encyclopedia of New Zealand. Retrieved from http://www.teara.govt.nz/en/auckland-places/page-16

McCreanor, T., Rankine, J., Moewaka Barnes, A., Borell, B., Nairn, R., \& McManus, A-L. (2014). The association of crime stories and Maori in Aotearoa New Zealand print media. Sites, 11(1), 212-144.

McGregor, J. (2002). Crime news: The cutting edge. In J. McGregor \& M. Comrie (Eds.), What's news: Reclaiming journalism in New Zealand (pp. 81-95). Palmerston North, NZ: Dunmore.

McGregor, J., \& Te Awa, J. (1996). Racism and the news media. In P. Spoonley, C. MacPherson, \& D. Pearson (Eds.), Nga patai: Racism and ethnic relations in Aotearoa/ New Zealand (pp. 235-246). Palmerston North: Dunmore Press.

McKee, A. (2003). Textual analysis: A beginner's guide. Thousand Oaks, CA: Sage.

McRobbie, A. (1997). The Es and the Anti-Es: New questions for feminism and cultural studies. In M. Ferguson \& P. Golding (Eds.), Cultural studies in question (pp. 170186). London: Sage.

Meijer, I. C. (2013). When news hurts. Journalism Studies, 12(1), 13-28. doi: $1: 10.1080 / 1461670 x .2012 .662398$

Mila-Schaaf, K., \& Robinson, E. (2010). 'Polycultural' capital and educational achievement among NZ-born Pacific peoples. MAI Review, 1, 1-18. Retrieved from http:// www.review.mai.ac.nz/index.php/MR/issue/view/15

Mjos, O, J. (2012). Music, Social media and global mobility: My Space, Facebook, YouTube. Manhattan, NY: Routledge.

Misa, T. (2010, August 27). Auckland: The Pacific comes to Auckland. New Zealand Herald Online: Retrieved from: www.nzherald.co.nz/nz/news/article.cfm?c id=1\&objectid=10667079

Moewaka Barnes, A., Borell, B., Taiapa, K., Rankine, J., Nairn, R., \& McCreanor, T. (2012). Anti-Maori themes in New Zealand journalism; toward alternative practice. Pacific Journalism Review, 18(1), 195-216. Retrieved from http://go.galegroup.com. 
ezproxy.auckland.ac.nz/ps/i.do?ty $=\mathrm{as} \& \mathrm{v}=2$.learn\& $\mathrm{it}=\mathrm{search} \& \mathrm{~s}=\mathrm{RELEVANCE} \& \mathrm{p}=\mathrm{A}$ ONE\&qt=SN 1023-9499 TI Anti-Maori\%20themes\%20in\%20New VO 18 SP 195 IU 1\&lm=DA 120120000\&sw=w

Nairn, R., Moewaka Barnes, A., Borell, B., Rankine, J., Gregory, A., \& McCreanor, T. (2012). Maori news is bad news: that's certainly so on television. Mai Journal, 1(1), 38-49. Retrieved from www.journal.mai.ac.nz/content/maori-news-bad-news-thatscertainly-so-television

Nakhid, C. (2012). 'Which side of the bridge to safety?' How young Pacific Islanders in New Zealand view their South Auckland community. Kotuitui: New Zealand Journal of Social Sciences Online, 7(1), 14-25. doi: 10:1080/1177083x.2012.670652

Nakhid, C., Tanielu, T, R., \& Collins, E. (2009). Pacific families now and in the future: Pacific youth in South Auckland. Family, gangs, community, culture, leadership and the future. Wellington, New Zealand: Families commission.

Noorzai, F. (2014). 'Inside' Muslims versus ‘outside' Muslims: Representation of Muslims in New Zealand online newspapers. Unpublished Masters thesis. Auckland, New Zealand: The University of Auckland.

O'Connor, P. (2014). A suicide of the soul: Neoliberalism, the arts and democracy. In V. M. Carpenter \& S. Osborn (Eds.), Twelve thousand hours. Education and poverty in Aotearoa New Zealand (pp. 260-264). Auckland, New Zealand: Dunmore.

'Ofa Kolo, F. (1990). An incident in Otara: The media and Pacific Island communities. In P. Spoonley \& W. Hirsh (Eds.), Between the lines: Racism and the New Zealand media (pp.120-122). Auckland, New Zealand: Heinemann Reed.

Richardson, L. (1990). Writing strategies: Reaching diverse audiences (Qualitative Research Methods Series 21). Newbury Park, CA: Sage.

Rankine, J., Moewaka Barnes, A., McCreanor, T., Nairn, R., McManus, A-L., Abel, S., Borell, B., \& Gregory, A. (2014). Content and source analysis of newspaper items about Māori issues: Silencing the 'natives' in Aotearoa? Pacific Journalism Review, 20(1), 213-233. doi: 10.24135/pjr.v20i1.195

Riddiford, J. (2015, November 4). Stuff and NZ Herald audiences continue to grow in Nielsen's latest online rankings. StopPress. Retrieved from: http://stoppress.co.nz/ news/kiwis-prefer-googling-and-facebooking-stuffs-popularity-growing

Ryan, S. (2014, June 24). Two stabbing incidents in South Auckland. The New Zealand Herald. Retrieved from www.nzherald.co.nz/nz/news/article.cfm?c id $=1$ \&objectid $=11280713$

Schoone, A. (2010). Re-scripting life: the experiences of New Zealand born Tongan 'youth at-risk' sent to Tonga. MAI Review, 1. Retrieved from www.review.mai.ac.nz/ index.php/MR/issue/view/15

Smith, C. (2014, June 24). Stabbing at South Auckland School. 3News online. Retrieved from www.3news.co.nz/Stabbing-at-south-Auckland-school/tabid/423/ articleID/349960/Default.aspx

Spoonley, P. (1990). Racism, race relations and the media. In P. Spoonley \& W. Hirsh (Eds.), Between the lines: Racism and the New Zealand media (pp. 26-37). Auckland, New Zealand: Heinemann Reed.

Spoonley, P. (2012). 'Ethnic and religious intolerance-Intolerance towards Pacific migrants'. Retrieved from www.teara.govt.nz/en/ethnic-and-religious-intolerance/page-4 Spoonley, P. \& Butcher, A. (2009). Reporting superdiversity. The mass media and immigration in New Zealand. Journal of Intercultural studies 30(4), 355-372. doi: $10.1080 / 07256860903213638$

Spoonley, P. \& Trlin, A. (2004). Immigration, immigrants and the media: making sense 
of multicultural New Zealand. Palmerston North, New Zealand: New Settlers Programme, Massey University.

Statistics New Zealand. (2015). 2013 Census map —QuickStats about a place [Data file]. Retrieved from www.stats.govt.nz/Census/2013-census/profile-and-summary-reports/ quickstats-about-a-place.aspx?request_value $=13170 \# 13170$

Statistics New Zealand, 2014: 2013 Census QuickStats about culture and identity. Retrieved from: www.stats.govt.nz/Census/2013-census/profile-and-summary-reports/ quickstats-culture-identity/pacific-peoples.aspx

Tapaleao, V. (2014, July 30). Martial arts saves street kid. The New Zealand Herald. Retrieved from www.nzherald.co.nz/sport/news/article.cfm?c_id=4\&objectid $=11301090$

Van Zoonen, L. (2012). I-Pistemology: Changing truth claims in popular and political culture. European Journal of Communication, 27, 56-67. Retrieved from http://ejc. sagepub.com.ezproxy.auckland.ac.nz/content/27/1/56.short

Walker, R. (2002). Maori news is bad news. In J. McGregor \& M. Comrie (Eds.), What's news: Reclaiming journalism in New Zealand (pp. 215-232). Palmerston North, NZ: Dunmore.

Wardle, C. (2008). Crime reporting. In B. Franklin (Ed.), Pulling newspapers apart: Analysing print journalism (pp. 144-152). Abingdon, Oxon, UK: Routledge.

Weekes, J. (2014, July 20). Two killed in pawn shop attack. The New Zealand Herald. www.nzherald.co.nz/nz/news/article.cfm?c id=1\&objectid=11296312

Wetherell, M., \& Potter, J. (1992). Mapping the language of racism. New York, NY: Columbia University Press.

Wilson, G. (1990). Journalists: Only partly professional. In P. Spoonley \& W. Hirsh (Eds.), Between the lines: Racism and the New Zealand media (pp. 47-52). Auckland, New Zealand: Heinemann Reed.

Jean M Allen is a doctoral student in the Faculty of Education and Social Work at the University of Auckland with special interests in social justice, power, privilege, media and health education.

jean.allen@auckland.ac.nz

Toni Bruce is a professor in the Faculty of Education and Social Work at the University of Auckland. Her media research focuses on representations of race and ethnicity, gender, disability and national identity, with a particular interest in sports media. 